\title{
Sifat Fisik, Kandungan Vitamin C dan Total Padatan Buah Pandan Tikar (Pandanus tectorius Park.) pada Tiga Tingkat Kematangan
}

\section{Physical properties, vitamin C and total soluble solids content of pandan tikar (Pandanus tectorius Park.) fruit on three maturity levels}

\author{
Devila Marker ${ }^{1}$, Zita Letviany Sarungallo ${ }^{1 *}$, Budi Santoso ${ }^{1}$, Rossa Martha Marlen Latumahina ${ }^{1}$, \\ Cicilia Maria Erna Susanti ${ }^{2}$, Nurhaidah Iriyani Sinaga ${ }^{3}$, Diana Nurini Irbayanti ${ }^{4}$ \\ ${ }^{1}$ Lab. Teknologi Pertanian, Fakultas Teknologi Pertanian, Universitas Papua. Jl. Gunung Salju, \\ Amban,Manokwari-98314, Papua Barat \\ ${ }^{2}$ Lab. Teknologi Hasil Hutan, Fakultas Kehutanan, Universitas Papua. Jl. Gunung Salju, Amban,Manokwari- \\ 98314, Papua Barat \\ ${ }^{3}$ Lab. Konservasi Sumber Daya Hutan dan Lingkungan, Fakultas Kehutanan, Universitas Papua. Jl. Gunung \\ Salju, Amban,Manokwari-98314, Papua Barat \\ ${ }^{4}$ Lab. Agribisnis, Fakultas Pertanian, Universitas Papua. Jl. Gunung Salju, Amban,Manokwari-98314, Papua \\ Barat \\ *Email: zlsarungallo@yahoo.com
}

\begin{abstract}
Pandan tikar (Pandanus tectorius Park.) fruit has the potential to be processed into various food products nevertheless the information on the right maturity level to be processed is limited. This study aims to determine the performance of pandan tikar fruit based on physical properties, vitamin $C$ and total soluble solids (TSS) content at three levels of maturity. The fruits were collected from tress that grown at Mansinam Island and costal area of Northern Manokwari. Observations were made to changes in fruit performance, including the shape, color, weight and size of the fruit drupa, the content of vitamin C as well as TSS in three maturity levels (semi-ripe, ripe and over-ripe). The results of this study indicate that the fruit shape of pandan tikar was oval and continue to develop in weight, width and length of whole fruit and part of fruit (drupa and pith) during maturity development. The color of semi-ripe phase was light yellow then change to yellow in ripe phase and dark yellow in over-ripe phase. The highest vitamin C content was obtained on pandan tikar fruit from costal area of Northern Manokwari, and the maximum of Vitamin C content found in the mature phase (138.3 $\mathrm{mg} / 100 \mathrm{~g})$, and then decreased in over-ripe phase $(49.5 \mathrm{mg} / 100 \mathrm{~g})$. The TSS were obtained on pandan tikar fruit from Mansinam Island, and will increase from 5.2 to $12.5{ }^{\circ}$ Brix with increasing fruit maturity level. The maximum Vitamin C and TSS of pandan tikar fruit found in the ripe and over-ripe phase; therefore the fruit in the phase is good for producting jam, dodol and syrup.
\end{abstract}

Keywords: Pandan tikar, maturity level of fruit, physical properties, vitamin C.

\begin{abstract}
Abstrak
Buah pandan tikar (Pandanus tectorius Park.) berpotensi untuk diolah menjadi berbagai produk pangan namun informasi mengenai tingkat kematangan yang tepat untuk diolah terbatas. Penelitian ini bertujuan untuk menentukan performa buah pandan tikar berdasarkan sifat fisik, kandungan vitamin $\mathrm{C}$ dan total padatan terlarut (TPT) pada tiga tingkat kematangan, yang berasal dari Pulau Mansinam dan pesisir Pantai Utara Manokwari. Pengamatan dilakukan terhadap perubahan performa buah yang meliputi bentuk, warna, berat dan ukuran drupa buah, serta kandungan vitamin C dan TPT selama perkembangan kematangan buah (fase buah agak matang, matang dan lewat matang). Hasil penelitian ini menunjukkan bahwa buah pandan tikar berbentuk bulat oval, yang selama perkembangan buah mengalami peningkatan ukuran berat, lebar dan panjang buah utuh maupun bagian buah (drupa dan empulur). Selama perkembangan kematangan buah pandan tikar mengalami perubahan warna kuning muda pada buah agak matang, menjadi kuning pada fase matang dan kuning tua pada fase lewat matang. Kandungan vitamin $\mathrm{C}$ tertinggi diperoleh pada buah pandan tikar yang berasal dari pesisir Pantai Utara Manokwari dan perubahan vitamin C meningkat maksimal dicapai pada fase matang
\end{abstract}


$(138,3 \mathrm{mg} / 100 \mathrm{~g})$ namun menurun pada fase lewat matang $(49,5 \mathrm{mg} / 100 \mathrm{~g})$. Kandungan vitamin C buah pandan tikar maksimal terdapat pada fase matang dan lewat matang. TPT tertinggi diperoleh pada buah pandan tikar yang berasal dari Pulau Mansinam, dan akan meningkat dengan bertambahnya tingkat kematangan buah yaitu dari $5,2{ }^{\circ}$ Briks menjadi $12,5^{\circ}$ Briks. Kandungan vitamin $\mathrm{C}$ dan total gula (TPT) buah pandan tikar maksimal terdapat pada fase matang dan lewat matang, karenanya buah pada fase tersebut baik untuk bahan baku berbagai produk seperti selai, dodol dan sirup.

Kata kunci: Pandan tikar, tingkat kematangan buah, sifat fisik, vitamin C.

\section{PENDAHULUAN}

Pandan tikar (Pandanus tectorius Park.) merupakan salah satu jenis dari kelompok Pandanaceae yang dijumpai tumbuh di sepanjang garis pantai pada daerah batas pasang surut air laut. Selain itu, tumbuhan ini dijumpai tumbuh pada formasi setelah tumbuhan mangrove, bersama-sama dengan vegetasi hutan pantai lainnya. Tapak tumbuhan ini adalah tanah berpasir, namun percobaan yang dilakukan, tumbuhan ini mampu tumbuh dengan baik pada tanah dengan ketinggian tempat hingga $100 \mathrm{~m} \mathrm{dpl}$ (Sinaga $d k k .$, 2014).

Jenis ini memiliki banyak manfaat baik manfaat langsung dan manfaat tidak langsung. Daun tumbuhan dan perakaran merupakan bahan baku yang baik untuk produk serat alami (Haryadi $d k k .$, 2015) dan bahan handycraft. Penduduk di Kepulauan Pasifik dan Mikronesia memanfaatkan buahnya sebagai bahan pangan, dengan cara dikonsumsi segar, atau daging buahnya diekstrak dan dimasak atau diawetkan (Englberger $d k k$., 2003).

Buah pandan tikar dilaporkan Sarungallo $d k k$. (2018) mengandung protein (2,8-4,3\%; bk), lemak (0,4-0,5\%; bk), abu (5,15-6,8\%; bk), karbohidrat (71,6-89,9\%; bk), serat kasar (24,4-27,3\%; bk), dan $\beta$-karoten (11,2-33,2 ppm; bk). Gurmeet dan Amrita (2015) juga melaporkan bahwa buah pandan tikar mengandung vitamin $\mathrm{C}$, tiamin, riboflavin, dan niacin (vitamin B3). Dijelaskan pula bahwa setiap macam buah mempunyai komposisi yang berbeda dan dipengaruhi oleh beberapa faktor yaitu perbedaan varietas, keadaan iklim tempat tumbuh, pemeliharaan tanaman, cara pemanenan, tingkat kematangan waktu panen, kondisi selama pemeraman dan kondisi penyimpanan (Muchtadi $d k k$., 2010).

Komposisi kimia dan komponen aktif dari suatu buah hanya dapat diperoleh dari buah dengan kualitas baik dengan tingkat kematangan optimum (Santoso $d k k$., 2011). Pada dasarnya tingkat kematangan buah dapat ditentukan berdasar kenampakan secara visual (warna dan bentuk buah), sifat fisik (bertambahnya ukuran buah), kimia (berdasarkan kandungan gizi yang terdapat pada buah) (Nurhayati, 2004). Lebih lanjut dijelaskan bahwa bahwa dengan umur buah dapat dihitung mulai dari bunga mekar (pemanenan buah yang terhitung mulai dari bunga mekar sampai waktu panen) dan secara fisiologis yaitu dengan mengukur laju respirasinya (Nurhayati, 2004). Penentuan waktu panen yang akurat sebaiknya dilakukan dengan mengkombinasikan lebih dari satu metode guna memperoleh hasil panenan yang baik.

Oleh karena itu dalam penelitian ini penentuan waktu panen terhadap buah pandan tikar dilakukan dengan mengkombinasikan antara sifat fisik, kenampakan visual dan kimia agar diperoleh waktu panen yang tepat, sehingga dapat dimanfaatkan lebih lanjut sebagai bahan baku yang berkualitas untuk berbagai produk olahan pangan. Tujuan penelitian ini adalah untuk menentukan sifat fisik buah pandan tikar pada 3 (tiga) tingkat kematangan; menentukan kandungan vitamin $\mathrm{C}$, dan kandungan total padatan terlarut buah pandan tikar pada 3 (tiga) tingkat kematangan buah.

\section{METODOLOGI}

\section{Bahan dan Alat}

Bahan utama yang digunakan dalam penelitian ini adalah buah pandan tikar dengan tingkat kematangan yang berbeda. Sampel buah yang digunakan berasal dari pohon yang sama, yang berasal dari Pulau Mansinam dan kawasan pesisir Pantai Utara Manokwari, Kabupaten Manokwari, Provinsi Papua Barat. Bahan kimia yang digunakan untuk analisis vitamin C yaitu aquades, kalium iodida, amilum dan iodine.

Alat-alat yang digunakan terdiri dari timbangan analitik, mistar, pisau, nampan, kamera, alat titrasi, hand refaktometer (Atago $\mathrm{N}-1 \mathrm{E}$ brix $0-32 \%$; Japan), mortal, sentrifuge 
dan peralatan gelas seperti gelas beker, buret, pipet volum, pipet tetes, labu takar, erlenmeyer, sudip, gelas ukur dan tabung berulir.

\section{Metode Penelitian}

Penelitian ini menggunakan Rancangan Acak Lengkap (RAL) pada pengamatan kandungan vitamin $\mathrm{C}$ dan total padatan terlarut serta karakterisasi sifat fisik, Buah pandan tikar yang diamati berasal dari pohon yang sama dengan 3 (tiga) tingkat kematangan buah, yaitu: agak matang, matang, dan lewat matang. Jumlah buah yang diamati dari setiap lokasi sampling masing-masing sebanyak 3 buah untuk tiap tingkat kamatangan buah.

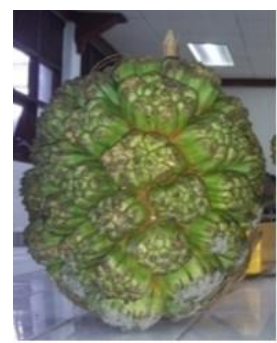

A

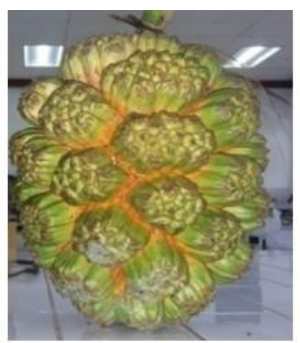

B

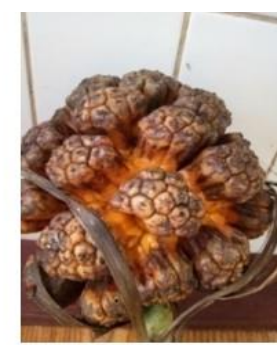

C

Gambar 1. Buah pandan tikar (Pandanus tectorius Park.) asal Pesisir Pantai Utara Manokwari; pada 3 tingkat kematangan yang berbeda; yaitu: (A) buah agak matang, (B) buah matang dan (C) buah lewat matang.

Karakerisasi sifat fisik buah utuh pandan tikar (Gambar 2 dan Gambar 3) pada 3 tingkat kematangan meliputi: Berat buah utuh; Bentuk buah utuh; Warna buah utuh; Panjang buah utuh; Lebar buah utuh; Lingkar buah utuh; Jumlah drupa per buah; Total berat drupa; Berat empelur: Penentuan berat empelur dilakukan dengan cara menimbang empelur.

Karakterisasi sifat fisik drupa pandan tikar (Gambar 2 dan Gambar 3) dilakukan pada 3 bagian dari buah utuh yaitu bagian pangkal, tengah, dan ujung. Pangkal buah adalah 1/3 bagian buah yang diukur mulai dari bagian tangkai buah, sedangkan bagian ujung buah adalah $1 / 3$ bagian buah yang diukur mulai dari ujung buah, dan bagian tengah buah adalah bagian yang terletak antara bagian pangkal dan

\section{Karakteristik Fisik Buah Utuh (Cephalum) dan Drupa}

Tingkat kematangan buah secara visual dicirikan dengan perubahan bentuk fisik buah, yaitu ukuran buah menjadi semakin besar dan jarak antar drupa yang semakin merenggang, serta terjadinya perubahan warna terutama pada bagian drupa yang dekat dengan empulur dimana warna berubah dari putih kekuningan menjadi kuning tua hingga orange, seperti yang disajikan pada Gambar 1 (Sarungallo $d k k ., 2018)$. bagian ujung. Selanjutnya karakterisasi drupa dilakukan dengan cara mengambil sebanyak 10 sampel drupa pada setiap bagian buah, tersebut dan diamati: Jumlah sub drupa; Lebar drupa; Panjang drupa; Rata- rata berat drupa; serta Persentase bagian buah yang dapat dimakan, yang dihitung dengan cara pemisahan bagian yang dapat dimakan dan dibandingkan dengan berat drupa utuh, dengan rumus sebagai berikut:

Keterangan:

$$
(\%) \mathrm{BDM}=\frac{\text { BDM }(\mathrm{g})}{\text { Berat drupa (g) }} \times 100 \%
$$

$\mathrm{BDM}=$ bagian buah yang dapat dimakan 


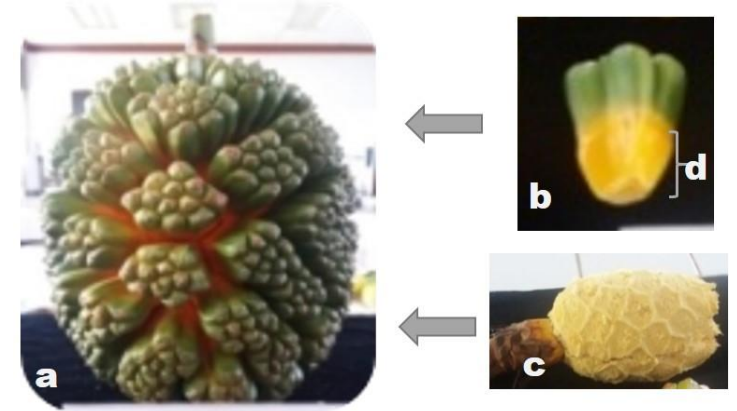

Gambar 2. Buah pandan tikar (Pandanus tectorius Park.); terdiri dari: (a) buah utuh (cephalum); (b) drupa; (c) empulur, dan (d) bagian buah (daging buah) yang dapat dimakan.

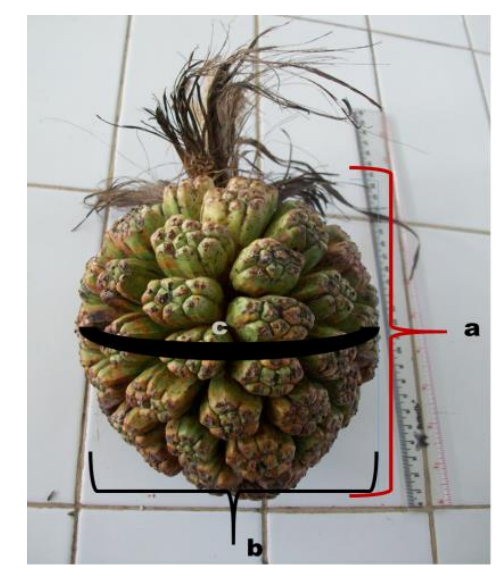

Gambar 3. Pengukuran dimensi buah pandan tikar (P. tectorius Park.), yaitu: (a) panjang buah utuh $(\mathrm{cm})$; (b) lebar buah utuh $(\mathrm{cm})$; (c) lingkar buah utuh (bagian tengah) $(\mathrm{cm})$

\section{Penentuan Kadar Vitamin C}

Proses analisis vitamin $\mathrm{C}$ menggunakan metode Titrimetri (Sudarmadji $d k k .$, 1997). Sampel daging buah dihancurkan sebanyak $10 \mathrm{~g}$ ditambahkan aguades, dalam labu takar $100 \mathrm{ml}$ kemudian disentrifiuse. Sampel difiltrate sebanyak 5-25 ml ke dalam erlemeyer. Ditambahkan $2 \mathrm{ml}$ amilum ke dalam erlemeyer, kemudian larutan tersebut dititrasi dengan mengunakan larutan $0,01 \mathrm{M}$ Iod standar. Titrasi diakhiri jika terjadi perubahan warna menjadi biru (tanda dimana kandungan vitamin $\mathrm{C}$ telah habis maka amilum akan bereaksi dengan Iod). Kandungan asam askorbat dihitung dengan rumus berikut:

$\operatorname{Vitamin} \mathrm{C}(\mathrm{mg} / 100 \mathrm{~g}$ bahan $)=$

$$
\frac{V \times N \times 0,88 \times F P \times 100 \%}{0,01 \times w}
$$

Keterangan :

$\mathrm{V}=$ Volume iod $(\mathrm{ml})$

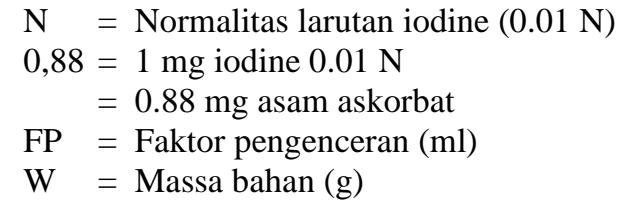

\section{Penentuan Total Padatan Terlarut}

Total padatan terlarut diukur dengan mengunakan hand refraktometer (Apriyantono $d k k .$, 1989). Pengukurannya dilakukan dengan cara, mempersiapkan sebagai berikut: sampel dan air dihancurkan di dalam mortal dengan perbandingan buah dan air 1:1. Kemudian cairan atau sari buah diteteskan di atas lensa refraktometer, kadar total padatan terlarut dapat dibaca pada kisaran $0-32{ }^{\circ}$ Briks.

\section{Analisis data}

Data karakterisasi fisik yang diperoleh dari penelitian ini dianalisis menggunakan statistik deskriptif yang disajikan dalam bentuk tabel dan gambar. Sedangkan data vitamin $\mathrm{C}$ dan total padatan terlarut (TPT) dianalisis 
menggunakan analisis sidik ragam (Analysis of Varians) dan jika terdapat perbedaan nyata maka dilakukan uji lanjut menggunakan DMRT (Duncans Multiple Range Test) dengan program SPSS (Statistical Productand Service Solution), versi 17,0.

\section{HASIL DAN PEMBAHASAN}

\section{Sifat Fisik Buah Utuh (Cephalum) Pandan Tikar pada Tiga Tingkat Kematangan}

Buah utuh atau cephalum pandan tikar secara fisik dapat digambarkan sebagai kumpulan bulir drupa yang tersusun rapat dan menempel kuat pada empulur (pedicel). Setiap drupa terdiri dari kumpulan sub drupa yang diselimuti oleh daging buah (pulp) yang di dalamnya terdapat biji yang jumlahnya setengah dari jumlah sub drupa. Daging buah dari buah pandan tikar merupakan bagian yang berwarna kuning dan dapat dikonsumsi.

Bentuk buah dan sayur dapat digolongkan menjadi bentuk round, oblate, oblong, conic, ovate, obovate, elliptical, truncate, uniegual, ribbed, regular, dan irregular (Mohsenin, 1986). Secara umum hasil penelitian ini menunjukkan bahwa buah utuh atau cephalum pandan tikar dalam satu pohon berbentuk agak bulat, bulat, oval, sampai lonjong. Buah pandan tikar asal pesisir Pantai Utara Manokwari memiliki cephalum yang berbentuk oval, sedangkan buah pandan tikar asal Pulau Mansinam berbentuk bulat lonjong. Adanya perbedaan bentuk buah tersebut dapat disebabkan karena perbedaan genetik ataupun karena pengaruh lingkungan tumbuhnya (Haris dan Karmas, 1989). Gurmeet dan Amrita (2015) melaporkan bahwa buah pandan tikar di Kepulauan Marshal (Micronesia) umumnya berbentuk oval.

Kematangan buah pandan tikar ditandai dengan performance dan perubahan warna pada buah. Karakterisasi fisik cephalum pandan tikar pada tiga tingkat kematangan, yang meliputi berat buah utuh, dimensi buah utuh, berat total drupa, berat empulur, jumlah drupa dan kadar air buah disajikan pada Tabel 1 .

Tabel 1. Karakterisasi fisik buah utuh pandan tikar pada tiga tingkat kematangan buah

\begin{tabular}{|c|c|c|c|c|c|c|c|c|}
\hline \multirow{2}{*}{\multicolumn{2}{|c|}{$\begin{array}{c}\text { Asal Buah } \\
\text { Tingkat } \\
\text { Kematangan }\end{array}$}} & & \multicolumn{3}{|c|}{ Pesisir Pantai Utara Manokwari } & \multicolumn{3}{|c|}{ Pulau Mansinam } \\
\hline & & & $\begin{array}{c}\text { Agak } \\
\text { Matang }\end{array}$ & Matang & $\begin{array}{c}\text { Lewat } \\
\text { Matang }\end{array}$ & $\begin{array}{c}\text { Agak } \\
\text { Matang }\end{array}$ & Matang & $\begin{array}{c}\text { Lewat } \\
\text { Matang }\end{array}$ \\
\hline \multirow{2}{*}{\multicolumn{2}{|c|}{$\begin{array}{c}\text { Berat } \\
(\mathrm{kg})\end{array}$}} & $\bar{x}$ & 2,1 & 2,5 & 3,3 & 2 & 2,5 & 3 \\
\hline & & $\sim$ & $1,7-2,5$ & $2-3,4$ & $3-3,5$ & $1,3-1,5$ & $2,4-2,5$ & 3 \\
\hline \multicolumn{2}{|c|}{ Panjang } & $\bar{x}$ & 18,5 & 20 & 21 & 19,5 & 22 & 22,5 \\
\hline \multirow{3}{*}{\multicolumn{2}{|c|}{$\begin{array}{c}(\mathrm{cm}) \\
\text { Lebar Buah } \\
(\mathrm{cm})\end{array}$}} & $\sim$ & $17-20$ & $19-21$ & $17-25$ & $19-20$ & $20-24$ & $21-24$ \\
\hline & & $\bar{x}$ & 16,5 & 17 & 18 & 18,5 & 19 & 19,5 \\
\hline & & $\sim$ & $15-18$ & $15-19$ & $13-23$ & $16-21$ & $16-22$ & $17-22$ \\
\hline \multirow{6}{*}{$\begin{array}{l}\text { Lingkar } \\
\text { Buah } \\
(\mathrm{cm})\end{array}$} & \multirow{2}{*}{ Pangkal } & $\bar{x}$ & 23,5 & 24,6 & 26 & 20,1 & 22,4 & 22,1 \\
\hline & & $\sim$ & $22-24,5$ & $23,8-25,5$ & $25,6-26,2$ & $20-20,2$ & $21-23,8$ & $21,5-22,8$ \\
\hline & \multirow{2}{*}{ Tengah } & $\overline{\bar{x}}$ & 27,5 & 28,8 & 30,1 & 31,4 & 32,8 & 36,5 \\
\hline & & $\sim$ & $27-28$ & $28,6-29,1$ & $29,7-30,5$ & $30,5-32,3$ & $33,4-32,2$ & $35,5-37,5$ \\
\hline & \multirow{2}{*}{ Ujung } & $\bar{x}$ & 20,9 & 21,8 & 25,8 & 20,4 & 22,9 & 22,4 \\
\hline & & $\sim$ & $20,5-21,3$ & $21,1-22,5$ & $23,5-28$ & $19,3-21,5$ & $22,5-23,3$ & $21,5-23,3$ \\
\hline \multirow{2}{*}{\multicolumn{2}{|c|}{$\begin{array}{c}\text { Berat } \\
\text { Empulur }(\mathrm{kg})\end{array}$}} & $\bar{x}$ & 1 & 0,6 & 0,3 & 0,9 & 0,7 & 0,4 \\
\hline & & $\sim$ & 1 & $0,4-0,7$ & $0,2-0,3$ & $0,5-1,3$ & $0,5-0,9$ & $0,2-0,5$ \\
\hline \multicolumn{2}{|c|}{ Berat } & $\overline{\bar{x}}$ & 1,9 & 2 & 2,3 & 1,1 & 1,8 & 2,1 \\
\hline \multicolumn{2}{|c|}{ Total Drupa (kg) } & $\sim$ & $1,5-2,2$ & $1,6-2,3$ & $2-2,5$ & $1-1,1$ & $1,5-2$ & $1,7-2,5$ \\
\hline \multicolumn{2}{|c|}{ Jumlah } & $\bar{x}$ & 54 & 54 & 54 & 70 & 70 & 70 \\
\hline \multicolumn{2}{|c|}{ Drupa (buah) } & $\sim$ & $41-60$ & $59-48$ & $62-71$ & $57-82$ & $69-70$ & $76-101$ \\
\hline \multicolumn{2}{|c|}{$\begin{array}{l}\text { Kadar air daging } \\
\left.\text { buah }(\%, b b)^{*}\right)\end{array}$} & & 78,68 & 79,53 & 78,04 & 76,64 & 76,93 & 74,21 \\
\hline
\end{tabular}

Keterangan $(\bar{x})$ rata; $(\sim)$ kisaran ; (bb) berat basah; ${ }^{*}$ Sarungallo $d k k ., 2018$ 
Tabel 1 menunjukkan bahwa ukuran buah pandan tikar pada fase agak matang relatif lebih kecil, setelah memasuki fase matang ukuran buah akan cenderung meningkat sampai pada fase lewat matang. Hal ini disebabkan karena pada fase agak matang masih merupakan proses pembentukan drupa, dan awal proses inisiasi drupa. Proses inisiasi maksimal drupa akan terjadi pada akhir proses pematangan atau awal fase matang. Santoso $d k k$. (2011) menjelaskan bahwa inisiasi bulir buah merah pada fase agak matang telah terjadi, namun belum maksimal yang terlihat dari rapatnya bulir yang saling menempel dan teksturnya masih sangat keras dan berserat. Lebih lanjut Santoso $d k k$. (2011) menjelaskan bahwa perubahan ukuran buah merah selama tahap perkembangan buah disebabkan karena terisinya drupa penuh dengan daging buah (pulp) Sementara pada buah lewat matang memiliki kadar air yang tinggi sehingga akan mempengaruhi berat buahnya. Syarief $d k k$. (1989) menjelaskan bahwa pada dasarnya pertumbuhan melibatkan pembelahan sel dan diteruskan dengan pembesaran sel yang bertanggung jawab terhadap ukuran maksimum sel buah. Ukuran buah pandan tikar asal Pami dan Pulau Mansinam lebih panjang tetapi tidak lebih berat dari buah pandan tikar asal Hawai seperti yang dilaporkan oleh Gurmeet dan Amrita (2015) bahwa buah pandan tikar asal Hawai memiliki panjang 6-10 cm, dan berat $4-8 \mathrm{~kg}$.

Lingkar buah pandan tikar asal pesisir Pantai Utara Manokwari dan Pulau Mansinam terus mengalami perubahan seiring meningkatnya tingkat kematangan buah. Lingkar cephalum pandan tikar pada bagian pangkal berkisar antara 20-26,2 cm, membesar pada bagian bagian tengah $27-37,5 \mathrm{~cm}$ dan mengecil bagian ujung berkisar antara 19,3-28 $\mathrm{cm}$.

Lingkar cephalum buah pandan tikar asal pesisir Pantai Utara Manokwari dan Pulau Mansinam mengecil pada bagian pangkal dan membesar pada bagian tengah kemudian mengecil kembali pada bagian ujung sehinga berbentuk bulat panjang dan oval. Lingkar buah pandan laut dalam penelitian ini sama seperti bentuk buah pandan tikar yang diteliti oleh Thomson $d k k$. (2006) bahwa buah pandan tikar asal Papua New Gunea dan Salomon berbentuk oval.

Berat empulur buah pandan tikar berkisar antar 0,2-1 kg (Tabel 1). Berat empulur dari kedua lokasi penelitian tersebut menunjukkan penurunan seiring dengan perubahan tingkat kematangan buah. Berat empulur buah pandan tikar asal pesisir Pantai Utara Manokwari hampir sama dengan buah pandana tikar asal Pulau Mansinam pada setiap tingkat kematangan buahnya. Penurunan berat empulur seiring dengan meningkatnya tingkat kematangan buah disebabkan karena, empulur merupakan tempat penyerapan zat gizi bagi keperluan drupa sehingga menyebabkan terjadi penurunan berat empulur. Keroman (2013) melaporkan bahwa terdapat variasi perubahan peningkatan berat empulur buah merah dimana buah merah kultivar Monsor mengalami peningkatan berat empulur pada fase muda sampai fase lewat matang yaitu berkisar antara 680-1 $300 \mathrm{~g}$, sedangkan kultivar Edewewits mengalami penurunan berat empulur pada fase agak matang sampai fase lewat matang yaitu berkisar antara 4 100-2 $800 \mathrm{~g}$.

\section{Karakterisasi Drupa Buah Pandan Tikar pada Tiga Tingkat Kematangan}

Drupa merupakan tempat melekatnya daging buah/pulp (Walujo dkk., 2007). Drupa buah pandan tikar asal pesisir Pantai Utara Manokwari dan Pulau Mansinam berbentuk lonjong, serta memiliki drupa dalam jumlah yang banyak, dan berserat (Gambar 1). Karakterisasi fisik drupa buah pandan tikar pada tiga tingkat kematangan buah disajikan dalam Tabel 2.

Data pada Tabel 2 menunjukkan bahwa ukuran drupa dari masing-masing tempat tumbuh sangat beragam. Ukuran drupa dengan lebar berkisar antara 3,6-6,5 cm, panjang 3,4-6,6 cm, berat $30,3-43 \mathrm{~g}$ yang terus mengalami peningkatan seiring dengan meningkatnya tingkat kematangan buah. Hal yang sama dijumpai Keroman (2013) pada buah merah (Pandanus conoideus), dimana drupa mengalami peningkatan ukuran panjang, lebar, bobot, dan persentase bagian yang dapat dimakan seiring dengan meningkatnya tingkat kematangan buah. 
Tabel 2. Karaktersasi fisik drupa buah pandan tikar pada tiga tingkat kematangan buah.

\begin{tabular}{cccccccc}
\hline Asal Buah & \multicolumn{3}{c}{ Pesisir Pantai Utara Manokwari } & \multicolumn{2}{c}{ Pulau Mansinam } \\
\hline $\begin{array}{c}\text { Tingkat } \\
\text { Kematangan }\end{array}$ & \multicolumn{2}{c}{$\begin{array}{c}\text { Agak } \\
\text { Matang }\end{array}$} & Matang & $\begin{array}{c}\text { Lewat } \\
\text { Matang }\end{array}$ & $\begin{array}{c}\text { Agak } \\
\text { Matang }\end{array}$ & Matang & $\begin{array}{c}\text { Lewat } \\
\text { Matang }\end{array}$ \\
\hline \multirow{2}{*}{ Lebar Drupa $(\mathrm{cm})$} & $\bar{x}$ & 3,8 & 4,1 & 4,1 & 5,3 & 5,5 & 5,6 \\
& $\sim$ & $3,6-4,2$ & $4-4,3$ & $4-4,3$ & $3,7-4$ & $4,5-6$ & $4,5-6,5$ \\
\hline \multirow{2}{*}{ Panjang Drupa $(\mathrm{cm})$} & $\bar{x}$ & 3,8 & 5,8 & 6,24 & 5,3 & 6,4 & 6,4 \\
& $\sim$ & $3,4-5,9$ & $5,5-6,1$ & $5,3-8$ & $5,8-6$ & $6-6,6$ & $5,9-6$ \\
\hline \multirow{2}{*}{ Berat Drupa $(\mathrm{g})$} & $\bar{x}$ & 42,4 & 43,5 & 43,3 & 33,0 & 35,1 & 40,5 \\
& $\sim$ & $37,4-45,2$ & $40,9-43$ & $33-43$ & $30,3-38$ & $33,9-37,3$ & $30-35$ \\
\hline Jumlah Sub Drupa & $\bar{x}$ & 10 & 10 & 10 & 13 & 13 & 13 \\
\hline \% Bagian yang Dapat & $\bar{x}$ & 10,1 & 11,31 & 12,99 & 12,05 & 13,92 & 14,45 \\
Dimakan & $\sim$ & $11-12,4$ & $13,2-18$ & $22,1-29,7$ & $22,4-28$ & $23,6-25$ & $19-25,3$ \\
\hline
\end{tabular}

Keterangan : $(\bar{x})$ rata-rata, $(\sim)$ kisaran

Pada Tabel 2 menunjukkan pula bahwa ukuran dan berat drupa buah asal pesisir Pantai Utara Manokwari lebih besar dibandingkan drupa buah asal Pulau Mansinam. Muchtadi $d k k$. (2010) menjelaskan bahwa setiap buahbuahan mempunyai sifat fisik yang berbedabeda dan dipengaruhi oleh varietas, tingkat kematangan, keadaan iklim tempat tumbuh dan pemeliharaan tanaman.

Sub drupa buah pandan tikar adalah tempat dimana terdapat biji dari buah pandan tikar. Tabel 2 memperlihatkan bahwa jumlah sub drupa asal pesisir Pantai Utara Manokwari dan Pulau Mansinam tetap, sehingga sudah tidak terjadi pembentukan sub drupa pada setiap tingkat kematangan buah. Hal ini disebabkan karena pada ke tiga fase tersebut merupakan tahap pengisian sub drupa.

Drupa pada buah pandan tikar terdapat bagian-bagian yang dapat dimakan dan tidak dapat dimakan (Gambar 2b). Bagian yang dapat dimakan atau disebut dengan daging buah, yaitu yang berwarna kuning (Gambar 2d), yang dikontribusi oleh kandungan karotenoidnya. Selama perkembangan tingkat kematangan buah yang agak matang berwarna kuning muda, pada fase matang kuning, dan selanjutnya pada fase over-ripe berwarna kunging tua/oranye (Gambar 1). Hal ini sejalan dengan laporan Sarungallo $d k k$. (2018) bahwa kadar $\beta$-karoten dari buah pandan tikar selama perkembangan tingkat kematangannya mengalami peningkatan. Sedangkan bagian buah yang tidak dimakan berwarna hijau (Gambar 1), karena memiliki tekstur yang sangat keras sehingga tidak dapat dikonsumsi.
Tabel 2 juga memperlihatkan bahwa berat bagian yang dapat dimakan meningkat seiring dengan meningkatnya tingkat kematangan buah yaitu berkisar antara 4,1-10,5 g per drupa

Pada Tabel 2, juga terlihat bahwa dengan meningkatnya tingkat kematangan buah, maka meningkat pula persen bagian yang dapat dimakan, berkisar antara 11 dan $29,7 \%$. Meningkatnya persen bagian yang dapat dimakan seiring dengan bertambahnya tingkat kematangan buah pandan tikar, untuk itu sangat berpotensi untuk dijadikan produk olahan pangan seperti selai, dodol, sirup, dan olahan lainnya.

\section{Kandungan Vitamin C Buah Pandan Tikar pada Tiga Tingkat Kematangan}

Buah pandan laut dilaporkan mengadung vitamin $\mathrm{C}$, riboflavin, niacin (vitamin B) dan thiamine (Gurmeet dan Amrita, 2015). Kandungan vitamin $\mathrm{C}$ buah pandan tikar pada tiga tingkat kematangan buah disajikan pada Gambar 4.

Kandungan vitamin $\mathrm{C}$ daging buah pandan tikar pada 3 (tiga) tingkat kematangan buah bervariasi yaitu 49,5 sampai 138,3 $\mathrm{mg} / 100 \mathrm{~g}$ bahan. Hasil analisi sidik ragam menunjukkan bahwa pada berbagai tingkat kematangan buah pandan tikar berpengaruh nyata terhadap kandungan vitamin C. Hasil uji lanjut Duncan pada tingkat kepercayaan 95\% menunjukkan bahwa kandungan vitamin $\mathrm{C}$ berbeda nyata pada setiap tingkat kematangan buah pandan tikar. 


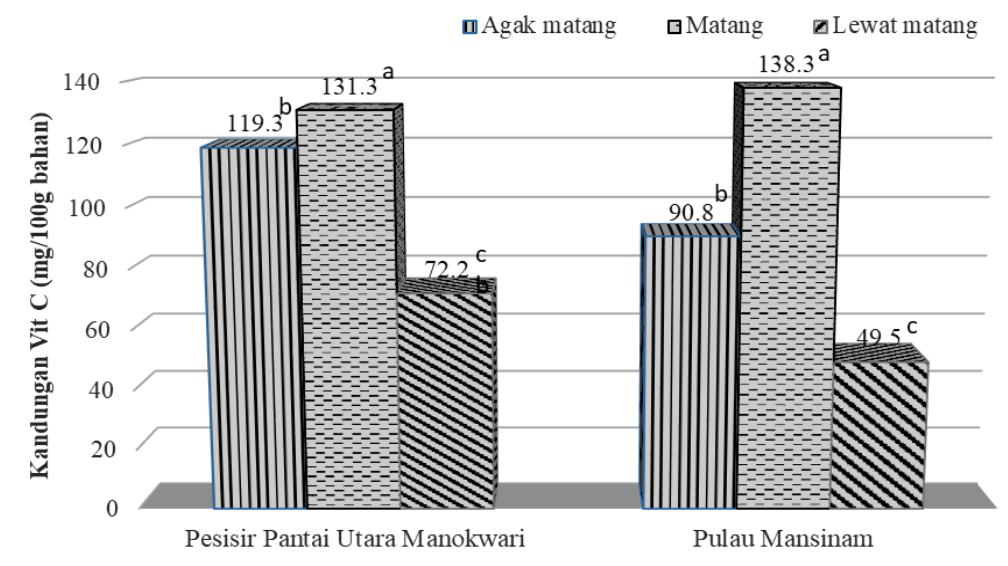

Ket :*) huruf yang berbeda di sebelah angka menunjukan perbedaan nyata $(\mathrm{P}<0,05)$ pada setiap asal buah

Gambar 4. Kandungan vitamin $\mathrm{C}$ buah pandan tikar pada 3 tingkat kematangan buah asal pesisir Pantai Utara Manokwari dan Pulau Mansinam

Rata-rata kandungan vitamin $\mathrm{C}$ buah pandan tikar yang paling rendah pada fase agak matang dan maksimal dicapai pada fase matang, yang mengindikasikan bahwa pada fase tersebut terjadi sintesis vitamin $\mathrm{C}$. Menurunnya kadar vitamin $\mathrm{C}$ pada fase lewat matang disebabkan karena meningkatnya kadar total padatan terlarut. Nikkhah (2007) melaporkan bahwa penurunan vitamin $\mathrm{C}$ dapat disebabkan oleh adanya proses degadasi vitamin $\mathrm{C}$ sebagai asam organik menjadi gulagula sederhana serta adanya proses oksidasi vitamin $\mathrm{C}$ atau asam askorbat menjadi asam diketoglukonat. Beberapa faktor dapat menyebabkan oksidasi atau kerusakan asam askorbat antara lain suhu, proporsi garam, proporsi gula, $\mathrm{pH}$, oksigen, cahaya, ion $\log \mathrm{Cu}$ dan Fe serta kadar air. Sebagai pembanding, Nurhayati (2004) melaporkan bahwa kandungan vitamin $\mathrm{C}$ pada buah rambutan yang masih muda lebih rendah dibandingkan buah yang sudah matang. Kandungan vitamin C pada buah pandan tikar (Gambar 4) lebih tinggi dibandingkan dengan buah jeruk keprok sebesar $22 \mathrm{mg} / 100 \mathrm{~g}$ bahan, mangga golek sebesar $20 \mathrm{mg} / 100 \mathrm{~g}$ bahan, dan papaya sebesar $59 \mathrm{mg} / 100 \mathrm{~g}$ bahan (Muchtadi dkk., 2010).

\section{Kandungan Total Padatan Terlarut Buah Pandan Tikar pada Tiga Tingkat Kematangan}

Pengukuran total padatan terlarut (TPT) dimaksudkan untuk mengetahui kandungan total gula pada buah (Buckle dkk., 1987). Kandungan total padatan terlarut buah pandan tikar pada tiga tingkat kematangan buah disajikan pada Gambar 5.

Kandungan total padatan terlarut daging buah pandan tikar pada 3 (tiga) tingkat kematangan buah bervariasi yaitu 5,2-12,5 ${ }^{\circ}$ Briks. Hasil analisi sidik ragam menunjukkan bahwa pada berbagai tingkat kematangan buah pandan tikar berpengaruh nyata terhadap total padatan terlarut. Hasil uji lanjut Duncan pada tingkat kepercayaan 95\% menunjukkan bahwa kandungan total padatan terlarut berbeda nyata pada setiap tingkat kematangan buah pandan tikar.

Total padatan terlarut pada fase agak matang berkisar antara 3-5 ${ }^{\circ}$ Briks, meningkat pada fase matang berkisar antara 5-7 ${ }^{\circ}$ Briks dan kemudian terus mengalami peningkatan sampai pada fase lewat matang dengan kisaran 10-12 ${ }^{\circ}$ Briks. Meningkatnya kadar total padatan terlarut tersebut disebabkan karena tingkat konversi pati menjadi gula meningkat seiring dengan perubahan tingkat kematangan buah. Pujimulyadi (2009) melaporkan bahwa semakin matang buah maka kandungan total gula di dalamnya akan semakin tinggi akibat adanya perubahan asam-asam organik dalam buah menjadi gula sederhana dan juga terjadi sintesis senyawa-senyawa seperti pati dan sukrosa. Diloporkan pula bahwa bahwa kadar total gula buah pandan tikar berbeda nyata antara 3 tingkat kematangan; dimana terdapat kecenderungan mengalami peningkatan pada fase matang kemudian menurun sampai pada fase lewat matang (Sarungallo dkk., 2018). 


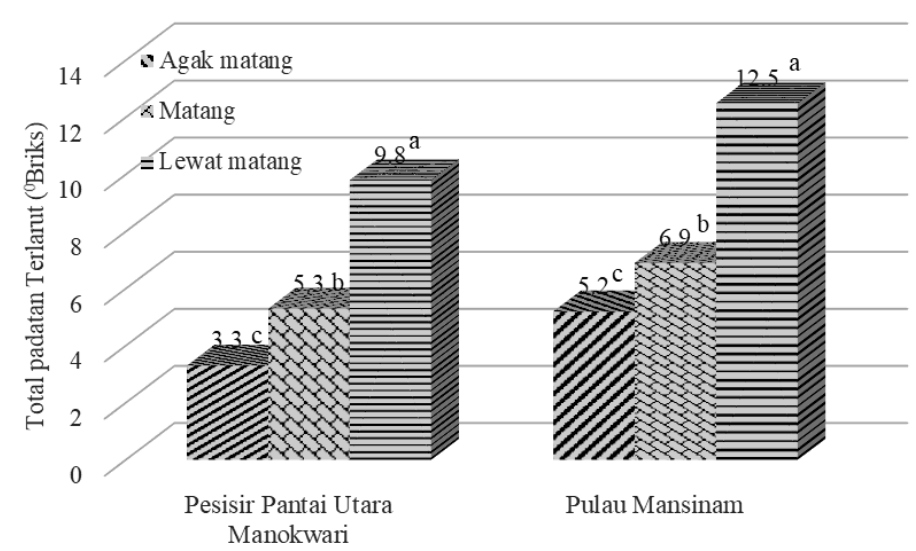

Ket :*) huruf yang berbeda disebelah angka menunjukan perbedaan nyata $(\mathrm{P}<0,05)$ pada setiap asal buah

Gambar 5. Kandungan Total Padatan Terlarut Kematangan Buah

Secara umum kandungan total padatan terlarut buah pandan tikar asal Pulau Mansinam cenderung lebih tinggi pada setiap tingkat kematangan buah $\left(5-12 \quad{ }^{\circ}\right.$ Briks $)$ dibandingkan kadar total padatan terlarut buah pandan tikar asal pesisir Pantai Utara Manokwari (3-10 ${ }^{\circ}$ Briks) kondisi ini dapat saja terjadi karena dipengaruhi oleh faktor lingkungan seperti suhu, dan keadaan fisiologis, misalnya aktifitas enzim (Sadat, 2015).

\section{KESIMPULAN}

Buah pandan tikar berbentuk oval dan bulat lonjong, yang selama perkembangan buah mengalami peningkatan ukuran buah utuh yaitu berat berkisar antara 1,7-3 kg, lebar berkisar antara 13-23 cm, panjang berkisar antara $17-25 \mathrm{~cm}$, lingkar pada bagian pangkal berkisar antara 20-26 cm, bagian tengah berkisar antara 27-38 cm, bagian ujung berkisar antara 19-28 cm, berat empulur 0,2$1,3 \mathrm{~kg}$, berat total drupa 1-3 kg, jumlah drupa 41-101 buah utuh maupun bagian buah (drupa dan empulur). Selama fase pematangan drupa buah pandan tikar mengalami perubahan yaitu lebar drupa berkisar antara 4-7 cm, panjang drupa berkisar antara 3-7 cm, berat drupa 30$45 \mathrm{~g}$, berat bagian yang dapat dimakan 4-11 g. Selama perkembangan kematangan buah pandan tikar mengalami perubahan warna kuning muda pada buah agak matang, menjadi kuning pada fase matang dan kuning tua pada fase lewat matang.
(TPT) Buah pandan tikar Pada 3 Tingkat

Kandungan vitamin $\mathrm{C}$ tertinggi diperoleh pada buah pandan tikar yang berasal dari pesisir Panta Utara Manokwari dan perubahan vitamin $\mathrm{C}$ meningkat maksimal dicapai pada fase matang $(138,3 \mathrm{mg} / 100 \mathrm{~g})$ namun menurun pada fase lewat matang $(49,5$ $\mathrm{mg} / 100 \mathrm{~g})$. Sedangkan total padatan terlarut (TPT) tertinggi diperoleh pada buah pandan tikar yang berasal dari Pulau Mansinam, dan akan meningkat dengan bertambahnya tingkat kematangan buah yaitu dari $5,2^{\circ} \mathrm{Briks}$ menjadi 12,5 ${ }^{\circ}$ Briks. Baik kandungan vitamin $\mathrm{C}$ maupun total padatan dari buah pandan tikar maksimal terdapat pada fase matang dan lewat matang. Oleh karena itu buah pandan tikar pada fase tersebut paling optimal untuk diproses menjadi berbagai produk seperti selai, dodol dan sirup.

\section{UCAPAN TERIMA KASIH}

Penulis mengucapkan terima kasih kepada Kemenristekdikti melalui Direktorat Riset dan Pengabdian Masyarakat (DPRM) Direktorat Jenderal Penguatan Riset dan Pengembangan atas dana penelitian skim MP3EI tahun 2016, sesuai dengan Surat Perjanjian Pelaksanaan $\begin{array}{llr}\text { Program Penelitian } & \text { nomor: }\end{array}$ Maret 2016. 


\section{REFERENSI}

Apriyantono, A., D. Fardiaz, S.N. Puspitasari, Sendarwati dan S. Budiyanto. 1989. Analisis Pangan. Depertemen Pendidikan dan Kebudayaan. Pusat Antar Universitas Pangan dan Gizi. Institut Pertanian Bogor, Bogor.

Buckle, K. A., R.A. Edwards, G.H. Fleet dan M. Wotton. 1987. Ilmu. Pangan. Penerjemah Hari Purnomo dan Adiono. Universitas. Indonesia Press. Jakarta.

Englberger, L, M.H. Fitzgerald dan G.C. Marks. 2003. Pacific Pandanus Fruit: An Ethnographic Approach to Understanding an Overlooked Source of Provitamin A Carotenoids. Asia Pacific Journal of Clinic Nutrition. Vol. 12 (1): 38-44.

Gurmeet, S. dan P. Amrita. 2015. Unique Pandanus - Flavor, Food and Medicine. Jurnal of Pharmacognosy and Phytochemistry. Vol.3 (3): 08-14.

Harris, R. H. dan E. Karmas. 1998. Evaluasi gizi pada pengolahan bahan pangan. Penerjemah: Achmadi, S. Penerbit ITB, Bandung.

Haryadi, F., C.M.E. Susanti, E. Gunawan, dan N.I. Sinaga, 2015. Daun Pandanus tectorius Park. Potensinya sebagai Bahan Baku Produk Serat Alami. Jurnal Kehutanan Papuasia. Vol.1 (2): 121126.

Keroman, S. 2013. Sifat Fisik Buah Selama Tahap Perkembangan Buah Merah (Pandanus conoideus Lamk.). (Skripsi). Jurusan Teknologi Pertanian. Fakultas Pertanian dan Teknologi Pertanian, UNIPA: Universitas Papua. Manokwari.

Mohsenin, N. N. 1986. Physical Properties of Plant and Animal Materials. Gordon and Breach Science Pub. New York.

Muchtadi, T. R., Sugiyono dan A. Fitriyono. 2010. Ilmu Pengetahuan Bahan Pangan. Alfabeta. Bandung

Nikkhah, E., M. Khayamy, R. Heidari dan R. Jamee. 2007. Effect of Sugar Treatment on Stability of Anthocyanin Pigments in Berries. Journal of Biological Sciences. Vol.7 (8): 1412-1417.
Nurhayati, S. 2004. Kajian Sifat Fisik, Kimia dan Fisiologi terhadap Beberapa Tingkat Kematangan Buah Rambutan Varietas Si Macan di Kabupaten Gunung Kidul Yogyakarta. Jurnal Matematika, Sains dan Teknologi. Vol.5 (2): 85-96.

Pujimulyani, D. 2009. Teknologi Pengolahan Sayur-Sayuran dan Buah-Buahan. Graham Ilmu. Yogyakarta.

Sadat, A., Tamrin dan C. Sugianti. 2015. Pengaruh Pemeraman Menggunakan Batu Karbit $\left(\mathrm{CaC}_{2}\right)$ terhadap Sifat Fisik dan Kimia Buah Pisang Ambon (Musa paradisiaca var. sapientum (1.) kunt). Jurnal Rekayasa Pangan dan Pertanian. Vol. 3(4): 417-423.

Santoso, B., Murtiningrum dan Z.L. Sarungallo. 2011. Morfologi Buah Selama Tahap Perkembangan Buah Merah (Pandanus conoideus). Agrotek. Vol. 2 (6): 23-29.

Sinaga, N. I., C.M.E. Susanti, Z.L. Sarungallo dan Y. Kaber. 2014. Pengentasan Kemiskinan dan Ketahanan Pangan melalui Budidaya Pandanus tectorius Park. di Kawasan TN. Teluk Cenderawasih Kabupaten Teluk Wondama. (Laporan Penelitian Tahun Ketiga). Lembaga Penelitian Universitas Papua. Manokwari.

Sarungallo, Z.L., C.M.E. Susanti, N.I.Sinaga, D. N. Irbayanti, R. M. M. Latumahina. 2018. Kandungan Gizi Buah Pandan Laut (Pandanus tectorius Park.) pada Tiga Tingkat Kematangan. Jurnal Aplikasi Teknologi Pangan. Vol. 7 (1):21-26.

Sudarmadji, S. B. Haryono dan Suhardi. 1997. Prosedur Analisa Untuk Bahan Makanan dan Pertanian. Liberty. Yogyakarta.

Syarief, R., S. Santausa dan S. Ismayana. 1989. Teknologi Pengemasan Pangan. Penerbit PT. Media. Jakarta.

Thomson, L. A. J., L. Englberger, R.R.Guarino, R. R. Thaman dan C. Elevitch. 2006. Pandanus tectorius (Pandanus). Dalam: C. R. Elevitch (ed). Traditional Trees of Pasific Island: Their Culture, Environment and Use. Permanent Agriculture Resources, Holuala, Hawai; 
http://www.traditionaltree.org

Walujo, E. B., A. P. Keim dan M. J. Sadsoetoeboen. 2007. Kajian etnotaksonomi Pandanus conoideus Lamk. untuk menjembatani pengetahuan dan ilmiah. Berita Biologi. Vol.8 (5):176-178. 